\title{
Lymphocyte Apoptotic Process
}

National Cancer Institute

\section{Source}

National Cancer Institute. Lymphocyte Apoptotic Process. NCI Thesaurus. Code C40717.

Any apoptotic process occurring in a B cell, T cell or natural killer cell. 